\title{
The visual arts and medical education
}

\author{
Donatella Lippi ${ }^{1} \cdot$ Raffaella Bianucci $^{2,3,4} \cdot$ Simon Donell ${ }^{5}$ (i)
}

Received: 12 August 2019 / Accepted: 30 September 2019 / Published online: 12 October 2019

(c) European Society of Sports Traumatology, Knee Surgery, Arthroscopy (ESSKA) 2019

Using the humanities (art, poetry, drama, plays) [9] as part of medical education has been promoted over the last two decades. Enhancing reflective capacity [3], visual thinking strategies [9], and promoting clinical observation and professionalism [7] are areas where the humanities have a role. For trainers, the visual arts can be used to enhance clinical observation [2] with a Visual Thinking Strategy (VTS) where three questions can be asked [9]:

What's going on in this picture?

What do you see that makes you say that?

What else can you find?

These questions can also be used in an examination such as the European Board in Orthopaedics \& Trauma (EBOT). From time-to-time patients with pathology have been painted, as is seen notably seen in William Hogarth's mural of Jesus at the Pool of Bethseda at the staircase of St Bartholomew's North Wing, which includes patients with tuberculosis, and gout.

The Golden Age of Danish Painting was from 1800 to 1850 centred on Christoffer Eckersberg (178-1853) and

Simon Donell

s.donell@uea.ac.uk

Donatella Lippi

Donatella.lippi@unifi.it

Raffaella Bianucci

Raffaella.bianucci@unito.it

1 Department of Experimental and Clinical Medicine, University of Florence, Florence, Italy

2 Legal Medicine Section, Department of Public Health and Paediatric Sciences, University of Turin, Turin, Italy

3 Warwick Medical School, Biomedical Sciences, University of Warwick, Coventry, UK

4 UMR 7268, Laboratoire d'Anthropologie bio-culturelle, Droit, Etique \& Santé (Adés), Faculté de Médecine de Marseille, Marseille, France

5 Norwich Medical School, University of East Anglia, Norwich, UK included his students, one of whom was Wilhelm Bendz (1804-1832) [6]. Bendz was noted for his technical ability. His body of work is small, due to his early death possibly from pneumonia. In 1829, he painted Svulst i Regio Patellaris (Swelling in the Region of the Patella) (Fig. 1), which can be seen in the Medicinsk Museion, Copenhagen.

What is going on in this picture?

As can be seen, this painting depicts the right knee of a male in close-up with a large swelling anterior to the knee cap. The most likely diagnosis is a pre-patellar bursitis.

\section{What do you see that makes you say that?}

The orientation shows the shin to the right and thigh to the left and the prominence of the hamstring tendons confirms a right knee. The sex of the patient is not clear, but the muscular definition suggests a man. The swelling is smooth and round. The skin is slightly erythematous, suggesting that it is warm. This is in keeping with inflammation. The swelling has to be of the soft tissue in front of the patella, as opposed to a tumour of the patella, because there is an indented edge at its base. Tumours of the patella are extremely rare. The bursitis is unusually large, reflecting the access to medical services and the potential treatments at that time.

\section{What else can you find?}

The upper thigh is covered by a sheet. The leg is resting on padded blankets or canvas which is opened up to provide the background. The one under the thigh has a buckle. The one under the calf has a black ink stamp on it.

In an oral examination further questions could be:

What is the most likely history from this patient?

A direct blow, e.g. from a stick, is possible but a prepatellar bursitis is typically due to recurrent minor injury 


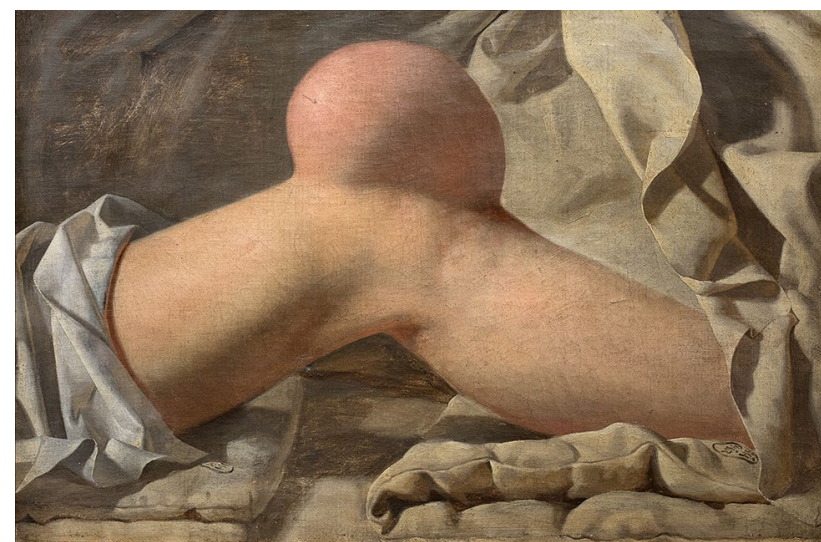

Fig. 1 Wilhelm Bendz, Svulst i Regio Patellaris (1829) (Swelling in the Region of the Patella), Medicinsk Museion, Copenhagen Copyright permission requested

Table 1 Four-step method for training clinical observation skills [4]

\begin{tabular}{|c|c|c|c|}
\hline $\begin{array}{l}\text { Observation } \\
\text { step }\end{array}$ & Goals & $\begin{array}{l}\text { Facilitator } \\
\text { questions }\end{array}$ & Student tasks \\
\hline Observation & $\begin{array}{l}\text { Identify objec- } \\
\text { tive visual } \\
\text { findings }\end{array}$ & $\begin{array}{l}\text { What do you } \\
\text { see? } \\
\text { What makes } \\
\text { you say that? } \\
\text { What else can } \\
\text { you see? }\end{array}$ & $\begin{array}{l}\text { Record observa- } \\
\text { tions without } \\
\text { judgements }\end{array}$ \\
\hline Interpretation & $\begin{array}{l}\text { Draw conclu- } \\
\text { sions about } \\
\text { the works } \\
\text { meaning }\end{array}$ & $\begin{array}{l}\text { What do you } \\
\text { think this } \\
\text { means? } \\
\text { What is your } \\
\text { visual dif- } \\
\text { ferential? }\end{array}$ & $\begin{array}{l}\text { Generate multi- } \\
\text { ple interpreta- } \\
\text { tions }\end{array}$ \\
\hline Reflection & $\begin{array}{l}\text { Evaluate con- } \\
\text { clusions and } \\
\text { test validity }\end{array}$ & $\begin{array}{l}\text { Does this make } \\
\text { sense to you? } \\
\text { How can your } \\
\text { beliefs bias } \\
\text { your observa- } \\
\text { tions? }\end{array}$ & $\begin{array}{l}\text { Consider per- } \\
\text { sonal beliefs } \\
\text { and bias }\end{array}$ \\
\hline $\begin{array}{l}\text { Communica- } \\
\text { tion }\end{array}$ & Share ideas & $\begin{array}{l}\text { Can someone } \\
\text { else make } \\
\text { a mental } \\
\text { image of your } \\
\text { description? }\end{array}$ & $\begin{array}{l}\text { Contribute to } \\
\text { group discus- } \\
\text { sion }\end{array}$ \\
\hline
\end{tabular}

whilst working on the knees. In our time it is seen in carpet layers, for instance. Colloquially it is known as "Housemaid's knee" due to scrubbing floors.

\section{What would you find on further examination?}

The swelling would be slightly mobile over the patella in all directions and not attached directly to it. It may transilluminate. The knee will also have a full range-of-motion.
What else could you do in the clinic to further confirm the diagnosis?

The swelling could be aspirated with a needle and syringe confirming the content is a yellow-green viscous fluid.

Training for clinical observation skills can involve larger groups using more complex pictures. Asensi et al. [1] speculated that Lorenzo Lotto depicted a Dominican friar with the traits of hypothyroidism Portrait of Frà Marcantonio Luciani of the Dominicans, as it shows alopecia, cold intolerance and thinning of the outer third of the eyebrow. Paintings used in established curricula include The Madness of Joanna of Castile by Lorenzo Vallés (1886) depicting Joanna refusing to bury her deceased husband (Philip I), believing he will be reanimated, Self-portrait with Dr. Arrieta Francisco de Goya (1820) where the artist is the patient, receiving treatment from his physician [4] and Healing the Deacon Justinian Giovanni da Fiesole (1443) where Saint Cosmas and Saint Damian transplant the (black) leg of a Moor onto the (white) body of deacon Justinian [5, 8]. To use these more sophisticated artworks in medical education a four-step method has been described (Table 1) [2]. It can be seen that the Visual Thinking Strategies are incorporated in the facilitator's questions column.

Traditional teaching has been didactic, with the teacher telling the students and trainees what they should know. Modern techniques aim to stimulate the student to articulate better, understand the subject, and retain the knowledge given. Using paintings is one way to do this.

\section{References}

1. Asensi V, Lippi D, Perciaccante A, Charlier P, Appenzeller O, Bianucci R (2019) Evidence of hypothyroidism in a portrait by Lorenzo Lotto. Lancet Diabetes Endocrinol 7:14

2. Jasani SK, Saks NS (2013) Utilizing visual art to enhance the clinical observation skills of medical students. Med Teach 35:e1327-e1331

3. Karkabi K, Wald HS, Castel OC (2014) The use of abstract paintings and narratives to foster reflective capacity in medical educators: a multinational faculty development workshop. Med Humanit 40:44-48

4. Katz JT, Khoshbin S (2015) Self portrait with Dr. Arrieta and the Medical Profession's Tenuous Status in the Public Eye. Open Forum Infect Dis 2:ofu077

5. Lippi D (2009) The transplant of the White Man's Leg: a novel representation of Cosmas' and Damian's Miracle. Intl J Immunopath Pharmacol 22:517-520

6. Mortensen KP (2001) Wilhelm Bendz. Søren Fogtdal, Denmark

7. Mukunda N, Moghbeli N, Rizzo A, Niepold S, Bassett B, DeLisser HM (2019) Visual art instruction in medical education: a narrative review. Med Educ Online 24:1558657. https://doi. org/10.1080/10872981.2018.1558657 
8. Perciaccante A, Rühli FJ, Galassi FM, Bianucci R (2016) Gangrene, amputation and allogenic transplantation in 5th century $\mathrm{AD}$, a pictorial representation. J Vasc Surg 64:824-825

9. Reilly JM, Ring J, Duke L (2005) Visual thinking strategies: a new role for art in medical education. Fam Med 37:250-252
Publisher's Note Springer Nature remains neutral with regard to jurisdictional claims in published maps and institutional affiliations. 